\title{
Recommendations of excavation and support systems of Pamukkulu Dam diversion tunnel based on correlation of rock mass classification between RMR and GSI
}

\author{
Dico Nasrulloh ${ }^{1,2}$, Agung Setianto ${ }^{1 *}$, and I Gde Budi Indrawan ${ }^{1}$ \\ ${ }^{1}$ Department of Geological Engineering, Engineering Faculty, Gadjah Mada University, Yogyakarta, Indonesia. \\ ${ }^{2}$ Ministry of Public Works and Housing, Jakarta, Indonesia.
}

\begin{abstract}
This paper presents the results of geological engineering research conducted to determine the character of rock masses, recommendations of tunnel excavation method and support system based on stand- up time estimates in unsuported conditions. The investigation was conducted by observing rock mass quality based on the newest bore log sample test results in 2019 using Rock Mass Rating (RMR) and Geological Strength Index (GSI) rock mass classification. The results showed that area consist of lithology in the form of porphyryc lava basalt and pyroclastic volcanic breccia. Rock mass has a slightly weathering alteration rates. Intact rocks have Uniaxial Compressive Strength (UCS) values ranging from 100-250 Mpa to $>250 \mathrm{Mpa}$ and are a category of strong rocks. Rock mass has fair to good rock quality class III-II based on RMR values between 53-69, GSI values between 48-64. The roof span required is obtained from the tunnel planning roof span of 10 meter, with a stand-up time of 70 hours without support system and immediate collapse for 5 days. The recommended excavation methods are excavation by drill and blast on top heading and bench: 1,5-3 meter advance in top heading tunnel face, and then can be recommended support system using rock bolts ( $20 \mathrm{~mm}$ diameter, fullly bonded): systematic bolts 4 meter long, spaced 1,5-2 meter in crown and bench with wiremesh in crown then shotcrete: 50-100 $\mathrm{mm}$ in crown, and $30 \mathrm{~mm}$ in sides, without steel ribs support.
\end{abstract}

\section{Introduction}

Geological investigation of subsurface engineering at the site of the diversion tunnel plan using the newest bore log test is carried out to know in detail the type of rock/soil, structure, the strength of rocks, permeability and thickness of the soil layer that will be used as a guideline to determine the design and geometry trace of the tunnel.

Therefore, adequate geological data is needed to support the right methods and stages to be able to reduce the risk of construction failure.

The purpose of the classification of rock mass is to group the types of rock mass based on his behavior, as the basis for understanding the character of each class, provide quantitative data to determine excavations methods and tunnel's support system.

This research aims to observe and analyze bore log test result to determine the quality of rock mass using Rock Mass Rating (Bienawski,1989) and Geological Strength Index (Hoek\&Brown, 2002) in the Pamukkulu's Dam diversion tunnel.

\footnotetext{
*Corresponding Author: agung_setianto@ugm.ac.id
}

And then determine the stand-up time of tunnel without support system to provide recommendations on excavation methods and tunnel support systems on tunnel's rocks that are effectively based on quality profile of rock mass.

Previous studies have been conducted to investigate the quality of rock mass with criepi's method. High uncertainty in that rock mass classification method requires more analysis of rock quality with other methods namely RMR and GSI, using the latest bore $\log$ test data investigation in 2019.

\subsection{Location}

Pamukkulu Dam is located in Kale Ko'Mara Village, North Polombangkeng District, Takalar Regency, South Sulawesi Province, Indonesia. Diversion tunnel using horseshoe shape with dimensions, diameter 7 meters, 370 meter long section. 


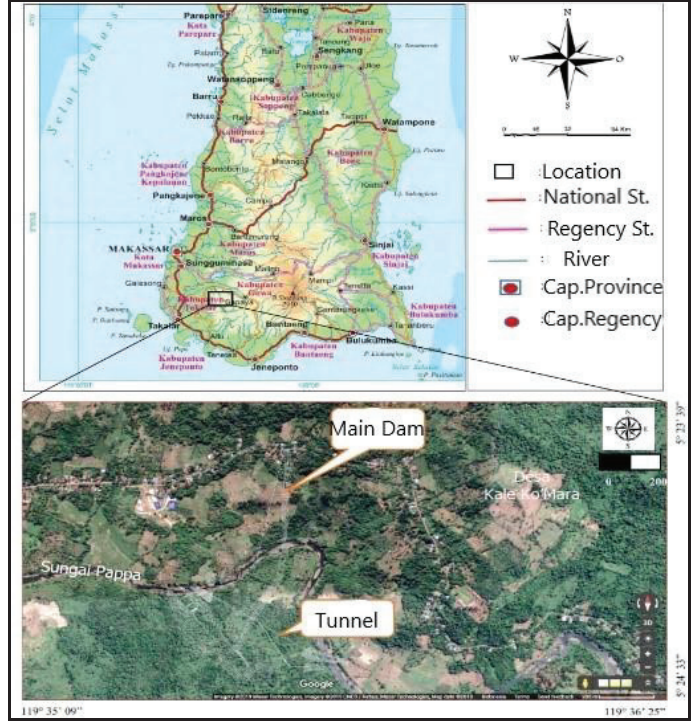

Fig. 1. Location Map

\section{Geological condition}

\subsection{Lithology}

The research area is located in the southern part of Sulawesi, based on a regional geological map of Lembar Ujungpandang, Bantaeng and Sinjai, Sulawesi (Sukamto and Supriatna, 1982), it appears that the research area was influenced by several lithological formations consisting: Camba Formation (Tmc), Tonasa Formation (Temt), Coastal Alluvium Deposits (Qac) and Baturape Volcano Rocks-Cindako (Tpbv), is shown in Figure 2 below.

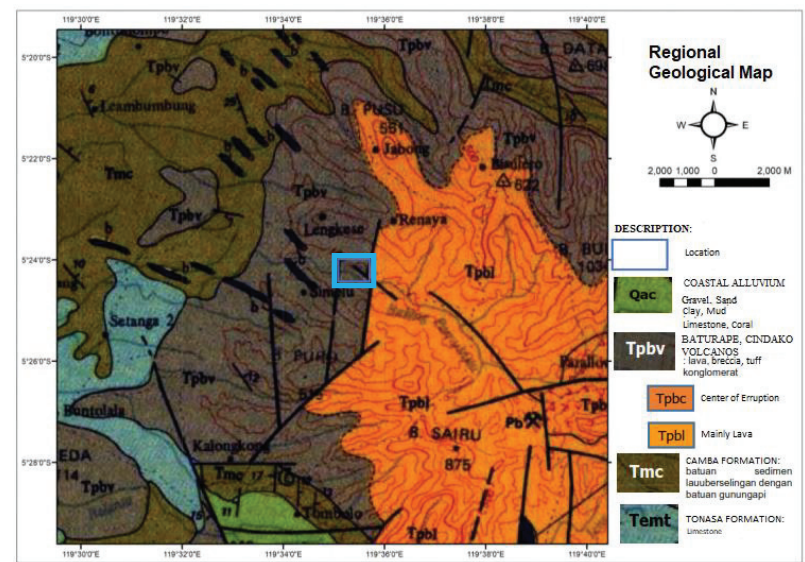

Fig. 2. Regional Geological Map sheet of Ujungpandang, Bantaeng and Sinjai, Sulawesi (Sukamto and Supriatna, 1982)

Research area dominated by residual soil, slightly weathered basalt lava group, fresh lava-breccia group and tuff lithology group, highly weathered breccia.

\subsection{Geological structure}

The geological structure in the research area is a fault down with $\mathrm{N}-\mathrm{S}$ and $\mathrm{W}-\mathrm{E}$ orientation. Fault is located on the northern part of the main dam, and extends along the coverage area of the dam.
Concerning active faults, the location is approximately $100 \mathrm{~km}$ west of the Walanae active fault northwest (NW) - southeast (SE).

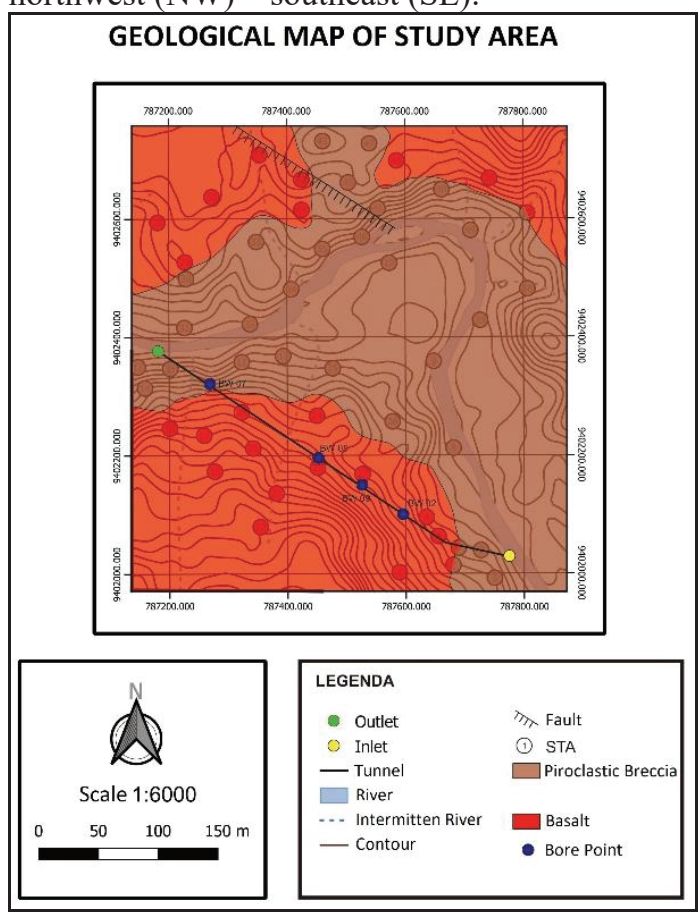

Fig. 3. Geological Map of Study Area

\section{Methodology}

\subsection{Rock mass rating (RMR)}

The main reason for using the Rock Mass Rating (RMR) classification method its ease and flexibility in a variety of practical purposes in engineering (Bieniawski, 1989). Rock Mass Rating is defined and calibrated based on observations and experiences of use

in the excavation civil construction and tunnels design.

This engineering classification system, Bieniawski developed in 1973-1989 utilizes the following six rock mass paramaters, including:

1. Uniaxial Compressive Strength of intact rock material

2. Rock Quality Designation (RQD)

3. Condition of discontinuities, given as:

- Persistance

- Separation

- Roughness

- Infilling

- Alteration/Weathering

4. Groundwater conditions

5. Orientation of discontinuities

All of these are measurable in the field and can also be obtained from borehole data. The rating of each of these parameters is summarised to give a value of Rock Mass Rating (RMR). All parameters are measurable in the field and some may also obtain of borehole data. 


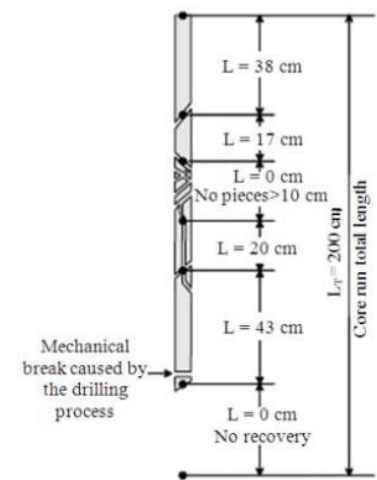

$\mathrm{RQD}=\frac{\sum \text { rock pieces }>10 \mathrm{~cm}}{\text { Core run total length }} \times 100(\%)$ $\mathrm{RQD}=\frac{38+17+0+20+43+0}{200} 100(\%)$

$\mathrm{RQD}=59 \%(\mathrm{FAIR})$

\begin{tabular}{|c|c|}
\hline RQD $(\%$ & Geotechnical quality \\
\hline$<25$ & Very poor \\
\hline $25-50$ & Poor \\
\hline $50-75$ & Fair \\
\hline $75-90$ & Good \\
\hline $90-100$ & Excellent \\
\hline
\end{tabular}

Fig. 4.Example calculation of RQD (Deere,et.al,1988)

Table 1. RMR classification parameters and ratings (Bieniawski, 1989)

\begin{tabular}{|c|c|c|c|c|c|c|c|c|c|}
\hline \multicolumn{3}{|c|}{ PARAMETER } & \multicolumn{7}{|c|}{ Range of values $/ /$ ratings } \\
\hline & \multirow{2}{*}{$\begin{array}{l}\text { Strength } \\
\text { of intact } \\
\text { rock } \\
\text { material }\end{array}$} & \multirow{2}{*}{\begin{tabular}{|l|}
$\begin{array}{l}\text { Point-load strength } \\
\text { index }\end{array}$ \\
$\begin{array}{l}\text { Uniaxial com- } \\
\text { pressive strength }\end{array}$ \\
\end{tabular}} & \multirow{2}{*}{$\begin{array}{l}>10 \mathrm{MPa} \\
>250 \mathrm{MPa}\end{array}$} & \multirow{2}{*}{\begin{tabular}{c|}
$4-10 \mathrm{MPa}$ \\
$100-250 \mathrm{MPa}$ \\
\end{tabular}} & \multirow{2}{*}{$\begin{array}{c}2-4 \mathrm{MPa} \\
50-100 \mathrm{MPa}\end{array}$} & \multirow{2}{*}{$\frac{1-2 \mathrm{MPa}}{25-50 \mathrm{MPa}}$} & \multicolumn{3}{|c|}{ 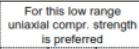 } \\
\hline & & & & & & & $\begin{array}{r}5-25 \\
\mathrm{MPa} \\
\end{array}$ & $\begin{array}{l}1.5 \\
\mathrm{MPa}\end{array}$ & $\begin{array}{l}<1 \\
\mathrm{MPa}\end{array}$ \\
\hline & & RATING & 15 & 12 & 7 & 4 & 2 & 1 & 0 \\
\hline \multirow{2}{*}{2} & \multicolumn{2}{|c|}{ Drill core quality RQD } & $90-100 \%$ & $75 \cdot 90 \%$ & $50-75 \%$ & $25-50 \%$ & \multicolumn{3}{|c|}{$<25 \%$} \\
\hline & \multicolumn{2}{|r|}{ RATING } & 20 & 17 & 13 & 8 & \multicolumn{3}{|c|}{5} \\
\hline \multirow{2}{*}{3} & Spacing of & discontinuties & $>2 \mathrm{~m}$ & $0.6-2 \mathrm{~m}$ & $200-600 \mathrm{~mm}$ & $60-200 \mathrm{~mm}$ & & $<60 \mathrm{~mm}$ & \\
\hline & & RATING & 20 & 15 & 10 & 8 & & 5 & \\
\hline \multirow{11}{*}{4} & \multirow{11}{*}{$\begin{array}{l}\text { Condition } \\
\text { of discon- } \\
\text { tinuities }\end{array}$} & Length, persistence & $<1 \mathrm{~m}$ & $1-3 m$ & $3 \cdot 10 \mathrm{~m}$ & $10-20 \mathrm{~m}$ & & $>20 \mathrm{~m}$ & \\
\hline & & Rating & 6 & 4 & 2 & 1 & & 0 & \\
\hline & & \begin{tabular}{|l|} 
Separation \\
\end{tabular} & none & $<0.1 \mathrm{~mm}$ & $0.1 \cdot 1 \mathrm{~mm}$ & $1.5 \mathrm{~mm}$ & & $>5 \mathrm{~mm}$ & \\
\hline & & Rating & 6 & 5 & 4 & 1 & & 0 & \\
\hline & & Roughness & very rough & rough & slightly rough & smooth & & lickenside & \\
\hline & & Rating & 6 & \multirow{2}{*}{\multicolumn{2}{|c|}{ Hard filling }} & 1 & & 0 & \\
\hline & & & none & & & \multicolumn{4}{|c|}{ Soff filling } \\
\hline & & IInfliling (gouge) & - & $<5 \mathrm{~mm}$ & $>5 \mathrm{~mm}$ & $<5 \mathrm{~mm}$ & & $>5 \mathrm{~mm}$ & \\
\hline & & Rating & 6 & 4 & 2 & 2 & & 0 & \\
\hline & & Weathering & unweathered & slightly w. & moderately w. & highly w. & & ecompos & \\
\hline & & Rating & 6 & 5 & 3 & 1 & & 0 & \\
\hline \multirow{4}{*}{5} & \multirow{4}{*}{$\begin{array}{l}\text { Ground } \\
\text { water }\end{array}$} & $\begin{array}{l}\text { Inflow per } 10 \mathrm{~m} \\
\text { tunnel length }\end{array}$ & none & $<10$ litres/min & $10-25$ litres/min & $25-125$ litres/min & & 125 litres I & \\
\hline & & $P_{w} / \sigma 1$ & 0 & $0-0.1$ & $0.1-0.2$ & $0.2-0.5$ & & $>0.5$ & \\
\hline & & General conditions & completely dry & damp & wet & dripping & & flowing & \\
\hline & & RATING & 15 & 10 & 7 & 4 & & 0 & \\
\hline
\end{tabular}

Table 2. Rating adjustment for discontinuity orientations (Bieniawski, 1989)

\begin{tabular}{|c|l|c|c|c|c|c|}
\hline \multicolumn{2}{|c|}{} & Very favourable & Favourable & Fair & Unfavourable & Very unfavourable \\
\hline \multirow{3}{*}{ RATINGS } & Tunnels & 0 & -2 & -5 & -10 & -12 \\
\cline { 2 - 8 } & Foundations & 0 & -2 & -7 & -15 & -25 \\
\cline { 2 - 7 } & Slopes & 0 & -5 & -25 & -50 & -60 \\
\hline
\end{tabular}

Table 3. Rock mass classes are determined from total ratings (Bieniawski, 1989)

\begin{tabular}{|c|c|c|c|c|c|}
\hline Rating & $100-81$ & $80-61$ & $60-41$ & $40-21$ & $<20$ \\
\hline & 1 & II & III & IV & $\mathrm{v}$ \\
\hline Description & VERY GOOD & GOOD & FAIR & POOR & VERY POOR \\
\hline \multicolumn{6}{|c|}{$\begin{array}{l}\text { Table 4. Meaning of rock mass classes (Bieniawski, } \\
\qquad 1989 \text { ) }\end{array}$} \\
\hline Class No. & 1 & II & IIII & IV & $\mathrm{v}$ \\
\hline Average stand-up time & $\begin{array}{l}10 \text { years for } \\
15 \mathrm{~m} \text { span }\end{array}$ & $\begin{array}{l}6 \text { months for } \\
8 \mathrm{~m} \mathrm{span}\end{array}$ & $\begin{array}{l}\begin{array}{l}1 \text { week for } \\
5 \mathrm{~m} \text { span }\end{array} \\
\end{array}$ & $\begin{array}{l}10 \text { hours for } \\
2.5 \mathrm{~m} \text { span }\end{array}$ & $\begin{array}{l}30 \text { minutes for } \\
1 \mathrm{~m} \mathrm{span}\end{array}$ \\
\hline Cohesion of the rock mass & $>400 \mathrm{kPa}$ & $300-400 \mathrm{kPa}$ & $200-300 \mathrm{kPa}$ & $100-200 \mathrm{kPa}$ & $<100 \mathrm{kPa}$ \\
\hline Friction angle of the rock mass & $<45^{\circ}$ & $35-45^{\circ}$ & $25-35^{\circ}$ & $15-25^{\circ}$ & $<15^{\circ}$ \\
\hline
\end{tabular}

\subsection{Geological strength index (GSI)}

GSI was introduced by Hoek (1994) and Hoek, Kaiser and Bawden (1995), can be used to estimating rock mass strength for different geology conditions, but it is less effective for poor or highly weathered rocks.

GSI can estimate the strength and deformation characteristics of rock masses that are required for underground excavation analysis. (Hoek and Brown, 1980).

One of the most important factors in estimating rock mass through GSI is to get Uniaxial Compressive Strength (UCS) values that describe level of weathering rocks that can known through laboratory test or using field estimates of UCS for intact rock pieces (Hoek et.al, 1998) [Table 3].

The next development of GSI is combined into 2 parameters the structure of the surface conditions in the form of roughness, weathering/alteration and fillers and block properties is described in Figure 5. (Hoek and Marinos, 2000).

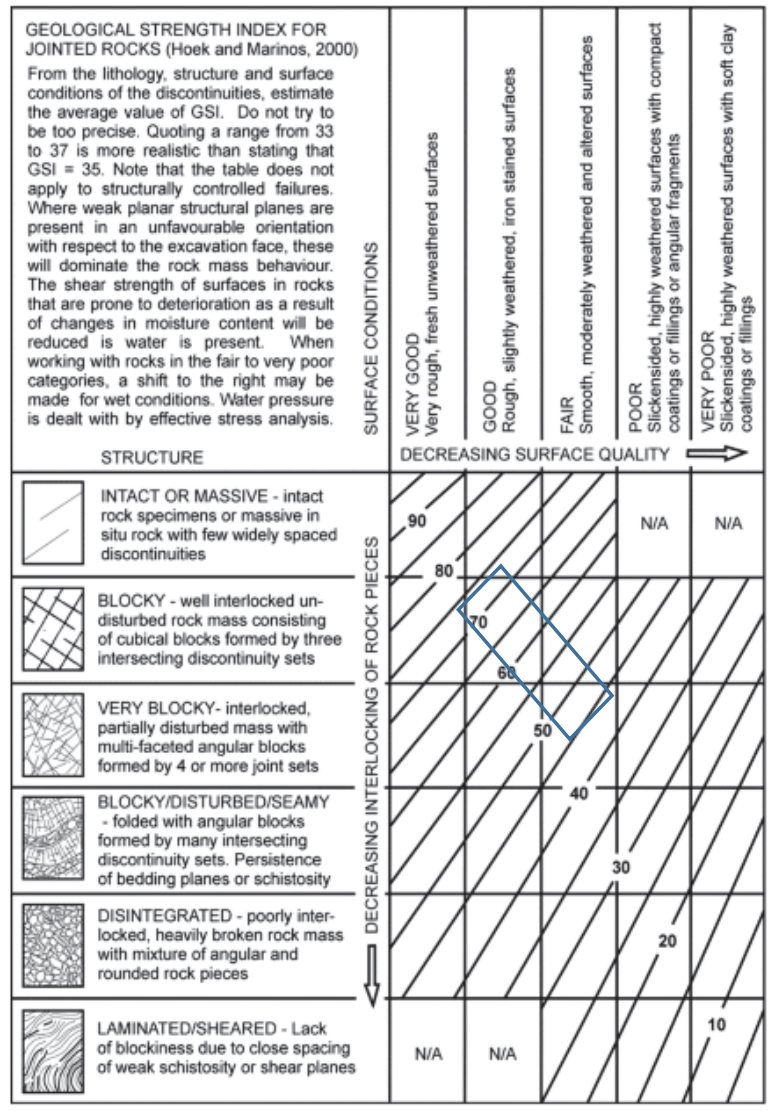

Fig. 5.Estimation value of GSI (Hoek and Marinos, 2000).

One of the most decisive factors in estimating rock mass through GSI is to obtain a Uniaxial Compressive Strength of intact rock material value that describes the level of weathering of rocks. The approximate value of UCS in the field according to Hoek et al. (1998) is seen in Table 5 below.

Table 5. Field estimates of UCS intack rock pieces

\begin{tabular}{|c|c|c|c|c|c|}
\hline Grade $^{2}$ & Term & $\begin{array}{l}\text { Uniaxial } \\
\text { compressive } \\
\text { strength } \\
\text { (MPa) }\end{array}$ & $\begin{array}{l}\text { Point } \\
\text { load } \\
\text { index } \\
\text { (MPa) }\end{array}$ & $\begin{array}{l}\text { Field estimate } \\
\text { of strength }\end{array}$ & Examples \\
\hline R6 & $\begin{array}{l}\text { Extremely } \\
\text { strong }\end{array}$ & $>250$ & $>10$ & $\begin{array}{l}\text { Specimen can only be chipped with a } \\
\text { geological hammer }\end{array}$ & $\begin{array}{l}\text { Fresh basalt, chert, diabase, gneiss, granite, } \\
\text { quartzite. }\end{array}$ \\
\hline R5 & $\begin{array}{l}\text { Very } \\
\text { strong }\end{array}$ & $100-250$ & $4-10$ & $\begin{array}{l}\text { Specimen requires many blows of a } \\
\text { geological hammer to fracture it }\end{array}$ & $\begin{array}{l}\text { Amphibolite, sandstone, basalt, gabbro, } \\
\text { gneiss, granodionite, limestone, marble, } \\
\text { thyolite, tuff }\end{array}$ \\
\hline R4 & Strong & 50-100 & $2-4$ & $\begin{array}{l}\text { Specimen requires more than one blow of a } \\
\text { geological hammer to fracture it }\end{array}$ & $\begin{array}{l}\text { Limestone, marble, phyllite, sandstone, schist } \\
\text { shale }\end{array}$ \\
\hline$R_{3}$ & $\begin{array}{l}\text { Medium } \\
\text { strong }\end{array}$ & $25-50$ & $1-2$ & $\begin{array}{l}\text { Cannot be scraped or peeled with a pocket } \\
\text { knife, specimen can be fractured with a } \\
\text { single blow from a geological hammer }\end{array}$ & $\begin{array}{l}\text { Claystone, coal, concrete, schist, shale, } \\
\text { siltstone }\end{array}$ \\
\hline$k_{2}$ & Weak & $5-25$ & b & $\begin{array}{l}\text { Can be peeled with a pocket knife with } \\
\text { difficulty, shallow indentation made by firm } \\
\text { blow with point of a geological hammer }\end{array}$ & Chalk, rocksalt, potash \\
\hline k1 & $\begin{array}{l}\text { Very } \\
\text { weak }\end{array}$ & $1-5$ & b & $\begin{array}{l}\text { Crumbles under firm blows with point of a } \\
\text { geological hammer, can be peeled by a } \\
\text { pocket knife }\end{array}$ & Highly weathered or altered rock \\
\hline Ro & $\begin{array}{l}\text { Extremely } \\
\text { weak }\end{array}$ & $0.25-1$ & b & Indented by thumbnail & Stiff fault gouge \\
\hline
\end{tabular}




\subsection{Correlation between RMR and GSI}

Classification of rock mass with the GSI system is a development of the rock mass classification of the RMR system. Hoek and Karzulovic (2000) explained that the mass of rocks with GSI $>25$ and RMR $>23$, GSI values can be calculated by the following Equation:

$$
\text { GSI }=\mathrm{RMR}_{89}-5
$$

The $\mathrm{RMR}_{89}$ value is the base of RMR value (Bieniawski, 1989) by providing a value of groundwater with a value weight of 15 (dry conditions) and a joint orientation value with weight of 0 (zero). The equation above should not be used for rock mass with very poor quality or with a GSI value $<25$.

Table 6. Quality class of rock mass based on a linear correlation between RMR and GSI rating (Hoek and Karzulovic, 2000)

\begin{tabular}{|c|c|c|c|c|c|}
\hline \multirow{2}{*}{$\begin{array}{c}\text { Rock Mass } \\
\text { Clasification }\end{array}$} & \multicolumn{5}{|c|}{ Rock Mass Quality } \\
\cline { 2 - 6 } & Very Poor & Poor & Fair & Good & Very Good \\
\hline RMR & $<21$ & $21-40$ & $41-60$ & $61-80$ & $81-100$ \\
\hline GSI & $<12$ & $12-30$ & $31-49$ & $50-68$ & $69-87$ \\
\hline
\end{tabular}

\subsection{Stand-up time}

The term stand-up time was first used by Lauffer in Lauffer's rock mass classification and then further developed by Lauffer for excavation using tunnel boring machines purposes. Stand-up time is defined as the length of time the tunnel can support itself without additional supporting structures.

The stand-up time estimation is very important because it will affect the excavation cycle, the required support structure, and the tunnel excavation method. The stand-up time developed by Lauffer is then correlated with rock mass classification and the most frequently applied in tunnel construction work is the RMR and stand-up time correlation by Bieniawski. The correlation by Bieniawski can be seen in Fig. 6 .

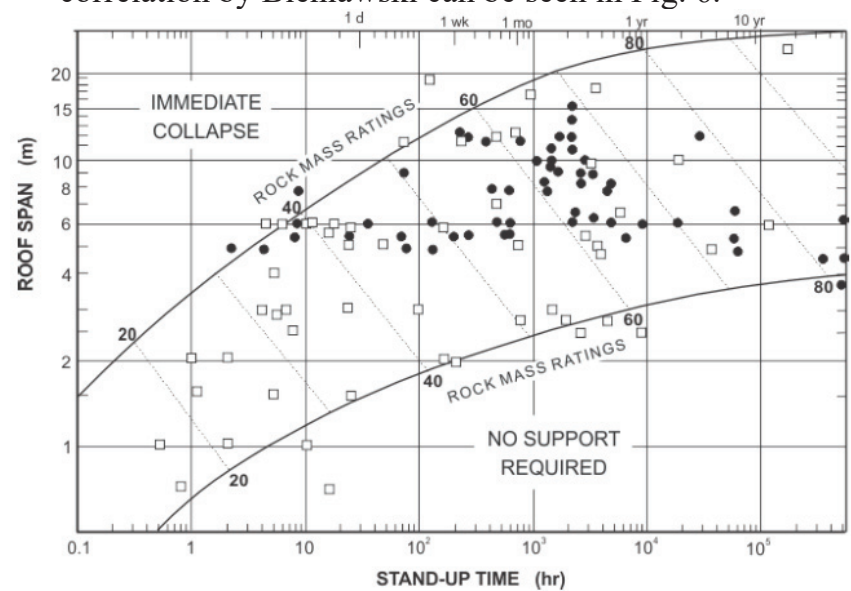

Fig.6. RMR classification of rock masses. (Countour lines indicate limits of applicability) (Bieniawski, 1989).

This study used the correlation between stand-up time and RMR to determine how long the roof span tunnel can withstand collapse without the tunnel's support system. The RMR value used to correlate with stand-up time is the lowest RMR value of each borehole point due to the correlation between GSI and RMR on the site.

\subsection{Excavation methods and support system}

Based on the lowest RMR value of each borehole point on diversion tunnel use to determine guide for excavation and support system in rock tunnels, provide that the tunnel is horseshoe shaped, roof span width 10 meters, vertical stress below $25 \mathrm{Mpa}$, using drill and blast methods.

Table 7. RMR classification guide for excavation and support in rock tunnels (Bieniawski, 1989).

\begin{tabular}{|c|c|c|c|c|}
\hline \multirow[b]{2}{*}{$\begin{array}{c}\text { Rock } \\
\text { mass class }\end{array}$} & \multirow[b]{2}{*}{ Excavation } & \multicolumn{3}{|c|}{ Support } \\
\hline & & $\begin{array}{c}\text { Rock bolts } \\
\text { (20 mm diam., fully } \\
\text { bonded) }\end{array}$ & Shotcrete & Steel sets \\
\hline $\begin{array}{l}\text { 1. Very good rock } \\
\text { RMR: } 81-100 \\
\end{array}$ & $\begin{array}{l}\text { Full face: } \\
3 \mathrm{~m} \text { advance } \\
\end{array}$ & \multicolumn{3}{|c|}{ Generally no support required except for occasional spot bolting } \\
\hline $\begin{array}{r}\text { 2. Good rock } \\
\text { RMR: } 61-80\end{array}$ & \begin{tabular}{|l|} 
Full face: \\
$1.0-1.5 \mathrm{~m}$ advance; \\
Complete support $20 \mathrm{~m}$ from \\
face
\end{tabular} & $\begin{array}{l}\text { Locally bolts in crown, } 3 \\
\mathrm{~m} \text { long, spaced } 2.5 \mathrm{~m} \\
\text { with occasional wire } \\
\text { mesh }\end{array}$ & $\begin{array}{l}50 \mathrm{~mm} \text { in crown } \\
\text { where required }\end{array}$ & None \\
\hline $\begin{array}{l}\text { 3. Fair rock } \\
\text { RMR: } 41-60\end{array}$ & $\begin{array}{l}\text { Top heading and bench: } \\
1.5-3 \mathrm{~m} \text { advance in top } \\
\text { heading; } \\
\text { Commence support after } \\
\text { each blast; } \\
\text { Commence support } 10 \mathrm{~m} \\
\text { from face }\end{array}$ & $\begin{array}{l}\text { Systematic bolts } 4 \mathrm{~m} \\
\text { long, spaced } 1.5-2 \mathrm{~m} \text { in } \\
\text { crown and walls with } \\
\text { wire mesh in crown }\end{array}$ & $\begin{array}{l}50-100 \mathrm{~mm} \text { in } \\
\text { crown, and } 30 \\
\mathrm{~mm} \text { in sides }\end{array}$ & None \\
\hline $\begin{array}{l}\text { 4. Poor rock } \\
\text { RMR: } 21-40\end{array}$ & \begin{tabular}{|l|} 
Top heading and bench: \\
$1.0-1.5 \mathrm{~m}$ advance in top \\
heading; \\
Install support concurrently \\
with excavation - $10 \mathrm{~m}$ from \\
face \\
\end{tabular} & $\begin{array}{l}\text { Systematic bolts } 4-5 \mathrm{~m} \\
\text { long, spaced } 1-1.5 \mathrm{~m} \text { in } \\
\text { crown and walls with } \\
\text { wire mesh }\end{array}$ & $\begin{array}{l}100-150 \mathrm{~mm} \text { in } \\
\text { crown and } 100 \\
\mathrm{~mm} \text { in sides }\end{array}$ & $\begin{array}{l}\text { Light ribs spaced } \\
1.5 \mathrm{~m} \text { where } \\
\text { required }\end{array}$ \\
\hline $\begin{array}{l}\text { 5. Very poor rock } \\
\text { RMR }<21\end{array}$ & \begin{tabular}{|l|} 
Multiple drifts: \\
$0.5-1.5 \mathrm{~m}$ advance in top \\
heading; \\
Install support concurrently \\
with excavation, shotcrete as \\
soon as possible after \\
blasting
\end{tabular} & $\begin{array}{l}\text { Systematic bolts } 5-6 \mathrm{~m} \\
\text { long, spaced } 1-1.5 \mathrm{~m} \text { in } \\
\text { crown and walls with } \\
\text { wire mesh. Bolt invert }\end{array}$ & $\begin{array}{l}150-200 \mathrm{~mm} \text { in } \\
\text { crown, } 150 \mathrm{~mm} \\
\text { in sides, and } 50 \\
\text { mm on face }\end{array}$ & $\begin{array}{l}\text { Medium to heavy } \\
\text { ribs spaced } 0.75 \mathrm{~m} \\
\text { with steel lagging } \\
\text { and forepoling if } \\
\text { required. Close } \\
\text { invert }\end{array}$ \\
\hline
\end{tabular}

\section{Result and discussion}

In this research has been investigated soil and rocks below the surface of the tunnel site using the following stages of work below:

1. Geological mapping and determination of bore $\log$ point location;

2. Conduct core bor tests at predetermined points

3. Description of rocks, determination of rock mass class and value, using correlation of RMR and GSI methods;

4. Determine how long the roof span tunnel can withstand collapse without the tunnel's support system [Fig.6];

5. Determine excavation methods and support system in rock tunnels[Table 7].

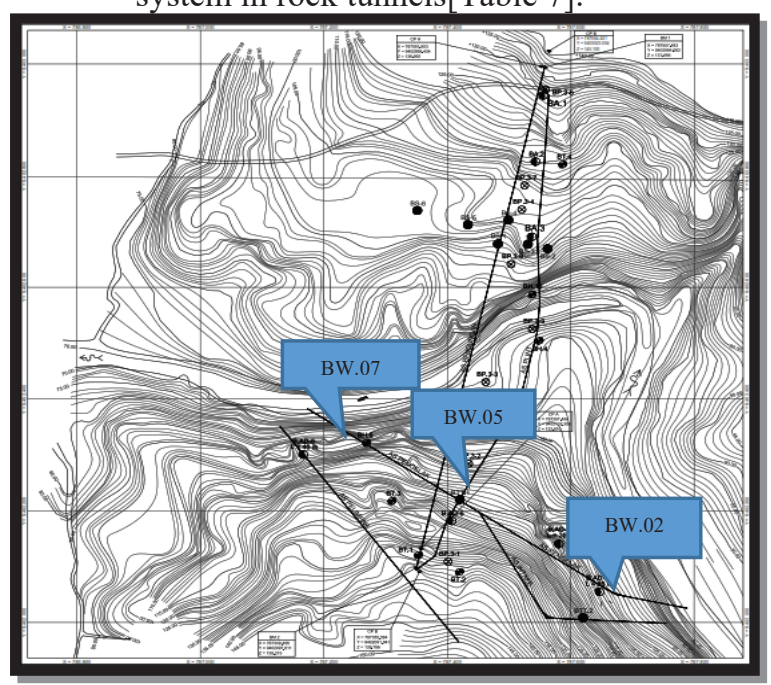

Fig. 7.Bor hole point test location in tunnel area (Soil\&Rock Investigation, 2020) 
Table 8. Bore log test distribution. (Soil\&Rock Investigation, 2020)

\begin{tabular}{|c|c|c|c|c|}
\hline No. & Bore Hole & Depth(m) & $\begin{array}{c}\text { Elevation } \\
\text { (mdpl) }\end{array}$ & Located \\
\hline 1 & BW.02 & 30 & 100.032 & Inlet \\
\hline 2 & BW.05 & 40 & 110.512 & Plinth\&Tunnel \\
\hline 3 & BW.07 & 40 & 105.918 & Outlet \\
\hline
\end{tabular}

Referring to rock mass classification (RMR and GSI) conducted observations on samples of core bor test results with the following results:

Table 9. Lithology description and rock mass rating on BW-02 (Inlet Tunnel)

\begin{tabular}{|c|c|c|c|c|c|c|c|c|c|c|c|c|c|c|}
\hline \multirow{3}{*}{ No } & \multirow{2}{*}{$\begin{array}{l}\text { Depth } \\
\text { (m) }\end{array}$} & \multirow{3}{*}{ Lithology } & \multirow{2}{*}{\multicolumn{10}{|c|}{$\begin{array}{c}\text { RMR (Bieniawski, 1989) } \\
\text { Classification Parameters }\end{array}$}} & \multirow{3}{*}{\begin{tabular}{|c|} 
RMR \\
Total \\
\end{tabular}} & \multirow{3}{*}{$\begin{array}{l}\text { GSI } \\
\text { (Hoek } \\
\text { Brown, } \\
2002)\end{array}$} \\
\hline & & & \multirow{2}{*}{ ucs } & \multirow[b]{2}{*}{ RQD(\%) } & \multirow{2}{*}{\begin{tabular}{|c|} 
Joint \\
Spacing \\
\end{tabular}} & \multicolumn{4}{|c|}{$\begin{array}{c}\text { Classification Parameters } \\
\text { Cond.of discontinuitie }\end{array}$} & \multirow{3}{*}{\begin{tabular}{|l|} 
Weather \\
\end{tabular}} & \multirow{2}{*}{ G.Water } & & & \\
\hline & From $\mid \mathrm{TC}$ & & & & & Disc. & \begin{tabular}{|l|} 
Sep. \\
\end{tabular} & Roughs & Infilling & & & AJ & & \\
\hline \multirow[b]{2}{*}{1} & \begin{tabular}{l|l}
0 & 8 \\
\end{tabular} & Soil Clay & & & & & & & & & & & & \\
\hline & & ting & & & & & & & & & & & & \\
\hline & \begin{tabular}{l|l}
9 & 15 \\
\end{tabular} & Basalt Porfiri & $100-250$ & 65,8 & \begin{tabular}{|l|}
$0,2-0,6$ \\
\end{tabular} & 3-10 & \begin{tabular}{|l|}
$0.1-1$ \\
\end{tabular} & Slight.R & $>5$ & Slight.w & Drip & Favour & & \\
\hline & & ting & 12 & 13 & 10 & 2 & 4 & 3 & 2 & 5 & 4 & -2 & 53 & 48 \\
\hline \multirow{2}{*}{3} & \begin{tabular}{|l|l|}
16 & 30 \\
\end{tabular} & Basalt Porfiri & $100-250$ & 75,2 & \begin{tabular}{|l|}
$0,2-0,6$ \\
\end{tabular} & $3-10$ & \begin{tabular}{|l|} 
\\
\end{tabular} & \begin{tabular}{|l|l|} 
Slight. \\
\end{tabular} & $>5$ & Slight.W & Wet & Favour & 60 & 55 \\
\hline & & ting & 12 & 17 & 10 & 2 & 4 & 3 & 2 & 5 & 7 & -2 & 60 & 55 \\
\hline
\end{tabular}

Source: Calculation

It was found that this area consists of lithology in the form of residual soil (clay and highly weathered sand) and porphyry lava basalt. Generally rock mass has a slightly weathering rate, and RMR value between 53-60 present category of class No.III describe as fair rock [Table 3].

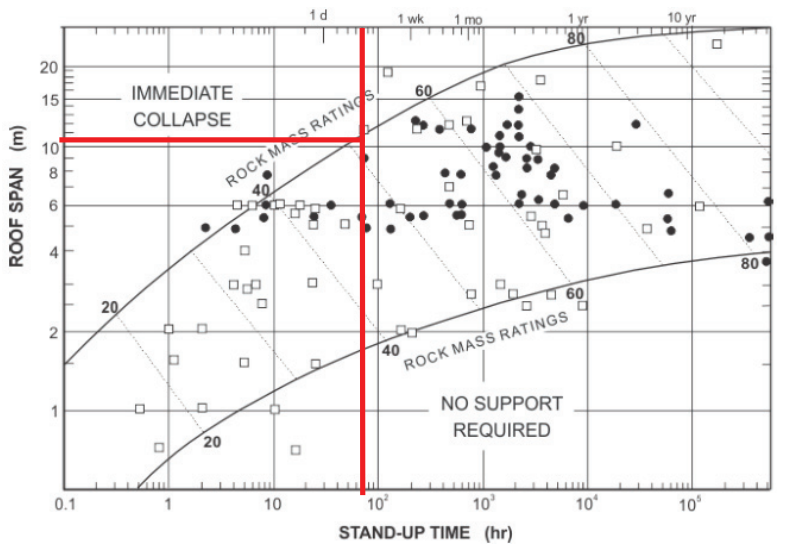

Fig. 8. Stand-up time based on BW.02 point (Inlet Tunnel)

Based on [Fig.8], the lowest RMR value at BW.02 borehole point is correlated using stand-up time chart by Bieniawski. The roof span required is obtained from the tunnel planning roof span of $10 \mathrm{~m}$, which has a stand-up time of 70 hours without rock support system and immediate collapse for 5 days.

Table 10. Lithology description and rock mass rating on BW-05 (Plinth\&Tunnel)

\begin{tabular}{|c|c|c|c|c|c|c|c|c|c|c|c|c|c|c|}
\hline \multirow{3}{*}{ No } & \multirow{2}{*}{$\begin{array}{c}\text { Depth } \\
\text { (m) }\end{array}$} & \multirow{3}{*}{ Lithology } & \multicolumn{10}{|c|}{$\begin{array}{l}\text { RMR (Bieniawski, 1989) } \\
\text { Classification Parameters }\end{array}$} & \multirow{3}{*}{\begin{tabular}{|l} 
RMR \\
Total
\end{tabular}} & \multirow{3}{*}{$\begin{array}{l}\text { GSI } \\
\text { (Hoek } \\
\text { Brown, } \\
\text { 2002) }\end{array}$} \\
\hline & & & \multirow{2}{*}{ ucs } & \multirow{2}{*}{ RQD(\%) } & \multirow{2}{*}{\begin{tabular}{|c|} 
Joint \\
Spacing
\end{tabular}} & \multicolumn{4}{|c|}{$\begin{array}{c}\text { Classification Parameters } \\
\text { Cond.of discontinuitie }\end{array}$} & \multirow{2}{*}{ |' Weather } & \multirow{2}{*}{ G.Water } & \multirow{2}{*}{ AJ } & & \\
\hline & \begin{tabular}{|l|l|} 
From & To \\
\end{tabular} & & & & & \begin{tabular}{|l|} 
Disc. \\
\end{tabular} & Sep. & Roughs & Infilling & & & & & \\
\hline & \multirow{2}{*}{\multicolumn{2}{|c|}{$\begin{array}{l}8 \text { S Soll lay } \\
\text { Rating }\end{array}$}} & & & & & & & & & & & & \\
\hline & & & & & & & & & & & & & & \\
\hline \multirow{3}{*}{2} & \begin{tabular}{l|l}
9 & 15 \\
\end{tabular} & Basalt Porfiri & $100-250$ & 65.8 & \begin{tabular}{|l|l}
$0.2-0.6$ \\
\end{tabular} & $3-10$ & $0.1-1$ & Slight.R & $>5$ & Slight.W & Drip & Favour & 53 & 48 \\
\hline & \multicolumn{2}{|c|}{ Rating } & 12 & 13 & 10 & 2 & 4 & 3 & 2 & 5 & 4 & -2 & & \\
\hline & \multicolumn{2}{|c|}{\begin{tabular}{l|l|l}
16 & 30 & Basalt \\
\end{tabular}} & \begin{tabular}{|c|}
$100-250$ \\
12
\end{tabular} & $\frac{75.2}{17}$ & \begin{tabular}{|l|}
$0.2-0.6$ \\
10
\end{tabular} & \begin{tabular}{|c|}
$3-10$ \\
2
\end{tabular} & \begin{tabular}{|c|}
$0.1-1$ \\
4
\end{tabular} & $\frac{\text { Slight.R }}{3}$ & $\frac{>5}{2}$ & \begin{tabular}{|c|} 
Slight.W \\
5
\end{tabular} & $\frac{\text { Wet }}{7}$ & \begin{tabular}{|c|} 
Favour \\
-2
\end{tabular} & 60 & 55 \\
\hline
\end{tabular}

Source: Calculation

It was found that this area consists of lithology in the form of residual soil (clay and highly weathered sand), porphyryc lava basalt and pyroclastic volcanic breccia. Generally rock mass has a slightly weathering rate, and RMR value between 54-69 present category of class No.II-III describe as fair to good rock [Table 3].

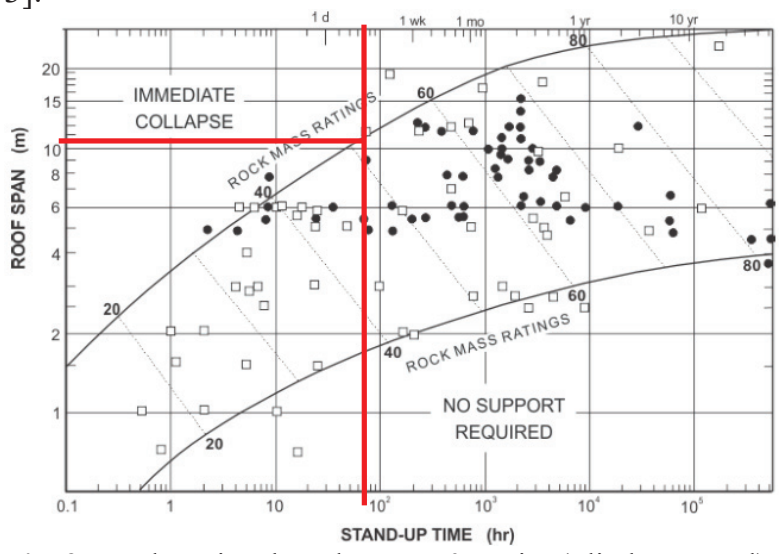

Fig. 9.Stand-up time based on BW.05 point (Plinth\&Tunnel)

Based on [Fig.9], the lowest RMR value at BW.05 borehole point is correlated using stand-up time chart by Bieniawski. The roof span required is obtained from the tunnel planning roof span of $10 \mathrm{~m}$, which has a stand-up time of 70 hours without rock support system and immediate collapse for 5 days.

Table 11. Lithology description and rock mass rating on BW-07 (Outlet Tunnel)

\begin{tabular}{|c|c|c|c|c|c|c|c|c|c|c|c|c|c|c|c|}
\hline \multirow{2}{*}{\multicolumn{3}{|c|}{$\begin{array}{c}\text { Depth } \\
\text { (m) }\end{array}$}} & \multirow{4}{*}{ Lithology } & \multirow{2}{*}{\multicolumn{10}{|c|}{$\begin{array}{l}\text { RMR (Bieniawski, 1989) } \\
\text { Classification Parameters }\end{array}$}} & \multirow{4}{*}{\begin{tabular}{|l} 
RMR \\
Total
\end{tabular}} & \multirow{4}{*}{$\begin{array}{l}\text { GSI } \\
\text { (Hoek } \\
\text { Brown, } \\
\text { 2002) }\end{array}$} \\
\hline & & & & & & & & & & & & & & & \\
\hline & Erom & To & & \multirow[t]{2}{*}{ UCS } & \multirow[t]{2}{*}{ RQD(\%) } & \multirow{2}{*}{$\begin{array}{c}\text { Joint } \\
\text { Spacing }\end{array}$} & & & . & ontinutite & Weather & \multirow[t]{2}{*}{ G.Water } & \multirow[t]{2}{*}{ AJ } & & \\
\hline & & & & & & & & & & & & & & & \\
\hline & 0 & 15 & Soil Clay & & & & & & & & & & & & \\
\hline \multirow{4}{*}{2} & \multicolumn{3}{|c|}{ Rating } & $100-250$ & 594 & 0.2-0.6 & $3-10$ & & Slight R & $>5$ & Slight W & $\mathrm{rin}$ & & \multirow[b]{2}{*}{53} & \multirow[b]{2}{*}{48} \\
\hline & & $\frac{24}{\mathrm{Ra}}$ & $\begin{array}{l}\text { Breccia Piro. } \\
\text { ting }\end{array}$ & 12 & 13 & $\mid$\begin{tabular}{|c|}
$\mid 0.200$ \\
\end{tabular} & 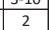 & \begin{tabular}{|c|}
.01 \\
\end{tabular} & 3 & 2 & 5 & $\frac{4}{4}$ & -2 & & \\
\hline & 25 & 40 & asalt Porfiri & $100-250$ & 82.9 & \begin{tabular}{|l|}
$0.3-10$ \\
\end{tabular} & $3-10$ & \begin{tabular}{|l|}
$0.1-1$ \\
\end{tabular} & Slight.R & $>5$ & Slight.W & Drip & Favour & \multirow{2}{*}{ ir 62} & \multirow[b]{2}{*}{57} \\
\hline & & & & 12 & 17 & 15 & 2 & 4 & 3 & 2 & 5 & 4 & -2 & & \\
\hline
\end{tabular}

Source: Calculation

It was found that this area consists of lithology in the form of residual soil (clay and highly weathered sand) and pyroclastic volcanic breccia. Generally rock mass has a slightly weathering rate, and RMR value between 53-62 present category of class No.II-III describe as fair to good rock [Table 3].

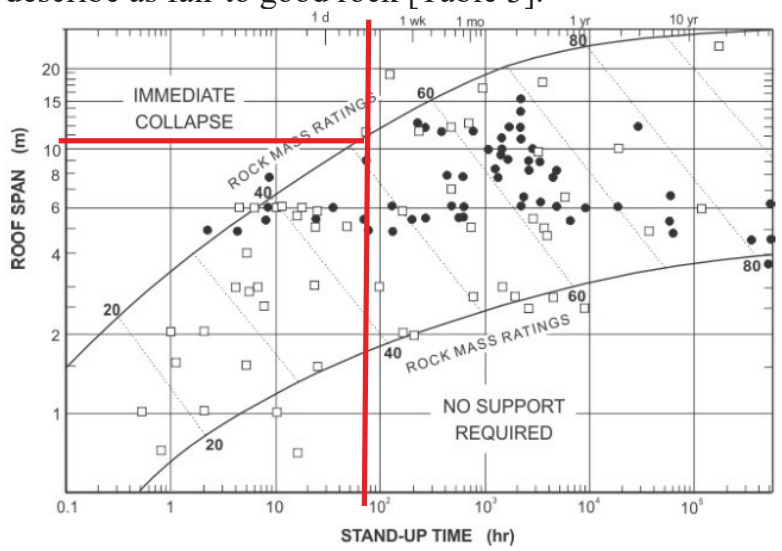

Fig. 10.Stand-up time based on BW.07 point (Outlet Tunnel)

Based on [Fig.10], the lowest RMR value at BW.05 borehole point is correlated using stand-up time chart by Bieniawski. The roof span required is obtained from the tunnel planning roof span of $10 \mathrm{~m}$, which has a stand-up time of 70 hours without rock support system and immediate collapse for 5 days. 


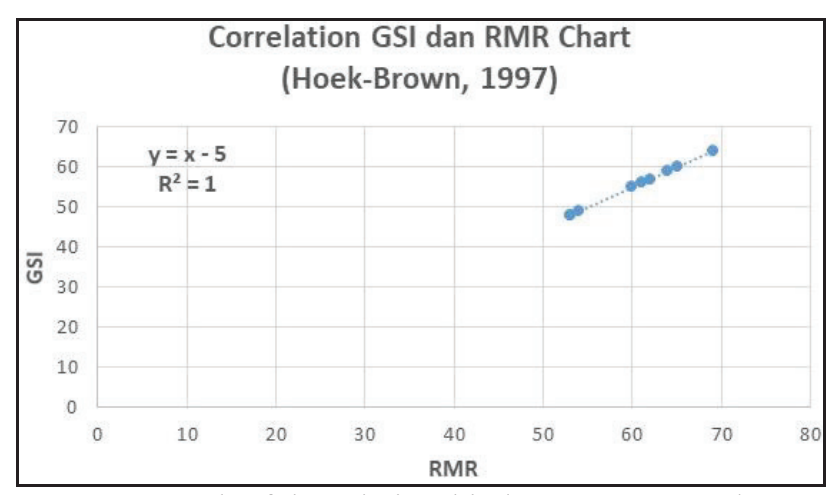

Fig. 11. Graph of the relationship between GSI and RMR

Based on the enrapture of bore data in the 3 points area described above, obtained an average RMR rock mass classification value of 60 , categorized as rock mass class no.II with a description of fair rocks[Table.3]

Refers to the tunnel's excavation method and support system guide (Bieniawski, 1989). in [Table.7], the recommended excavation method is:

a) Excavation by drill and blast;

b) Top heading and bench: 1,5-3 meter advance in top heading;

c) Commence support after each blast;

d) Commence support 10 meter from the face.

And then can also be recommended support system as follows below:

a) Rock bolts (20 $\mathrm{mm}$ diameter, fullly bonded): systematic bolts 4 meter long, spaced 1,5-2 meter in crown and walls with wiremesh in crown;

b) Shotcrete: $50-100 \mathrm{~mm}$ in crown, and $30 \mathrm{~mm}$ in sides.

Tunnel excavation by drill and blast methods is conducted by digging from inlet to outlet. Heavy equipment needed to support the work with conditions in the field are Jumbo Drill, Schaeff Tunnel Loader, and Dump Trucks.

Blasting work items in diversion tunnels include:

a) Explosive storage (Handak) retrieval

b) Depth survey and drilling;

c) Charging;

d) Blasting;

e) Smoke and dust cleaning;

f) Post-explosion rock cleaning and material loading.

The process of digging tunnels by drill and blast methods in one day can do blasting 1 time, and the results of excavation obtained 1,5-2 meter, so to dig a tunnel along 370 meter takes approximately 6 months.

\section{Conclusion and recommendation}

The research area consists of geological lithology in the form of residual soil (clay and weathered sand), porphyry lava basalt and pyroclastic volcanic breccia. Generally rock mass has slightly weathering rate.[Table 9-11].
Intact rock has Uniaxial Compressive Strength (UCS) values ranging from 100-250 Mpa and $>250$ Mpa and belongs to the category of rocks with very good strength. Geological Strength Index (GSI) rating between 48-64 and Rock Mass Rating (RMR) between 53-69 both presents categories of fair to good rocks class III-II [Table.5].

The average RMR value at every borehole point above is correlated using a stand-up time chart by Bieniawski[Fig.5]. The roof span required is obtained from the tunnel planning roof span of 10 meters, with a stand-up time of 70 hours without support system.

Refers to the tunnel's excavation method and support system guide in [Table.7], the recommended excavation method is excavation by drill and blast on top heading and bench tunnel face.

And then make recommendation tunnel's support system using rock bolts and wiremesh-shotcrete combination without steel ribs support.

The author gratefully acknowledges to the Ministry of Public Works and Housing for the support of research funding through the 2020's Superspecialist Scholarship Program at Geological Engineering of Tunnel and Underground Structure, Master by Research Program of Geological Engineering, Gadjah Mada University.

\section{References}

1. Z.T.Bieniawski, InJ.A.Hudson(Ed.) Classification of rock masses of rock engineering: The RMR system and future trends, comprehensive rock engineering, 3:553-574 (1993)

2. D. Deere, R. Miller, Engineering Classification and Index Properties for Intact Rock, in New Mexico: Technical Report No. AFWL-TR-65-116, Air Force Weapons Laboratory, Kirkland Air Force Base (1979)

3. E. Hoek, P. Marinos, M. Benissi, Bull Eng Geol Environ 57, 151-160 (1998)

4. P.G. Marinos, V. Marinos, E. Hoek, The Geological Strength Index (GSI):A characterization Tool for Assessing Engineering Properties of Rock Masses, 87-94 (2007).

5. Balai Besar Wilayah Sungai PompenganJeneberang, Soil and Rock Investigation Diversion Tunnel of Pamukkulu Dam, Takalar, in Geological Report (2020)

6. R. Sukamto, S. Supriatna, Peta Geologi Lembar Ujungpandang,Bantaeng dan Sinjai, Sulawesi, (1982) 